\title{
RULE OF LAW - CONDITION FOR ECONOMIC DEVELOPMENT (REPUBLIC OF MACDDONIA)
}

DOI: $10.1515 /$ seeur-2015-0022

\begin{abstract}
In this essay I will attempt to explain the relation between the rule of law and the economic development. First I will describe the rule of law and its role through the years. Then, I will continue with the connection between economic development and the rule of law. I will try to clarify Macedonia's legal framework and emphasize the constitution and its role regarding the rule of law and economic development. Latter, I will focus on the EU's report on our economy in our journey towards the union. And finally I will give something to think about for future researchers.
\end{abstract}

\section{RULE OF LAW}

"The clearest way to show what the rule of law means to us in everyday life is to recall what has has happened when there is no rule of law" Dwight D. Eisenhower

From its appearance till now the rule of law remains an important issue in legal theory and has been redefined many times. In legal theory there is a general view that the rule of law is essential to any modern legal system, but there is no single viewpoint in terms of determining it's scope and content. According to B.Tamanaha (2007) the rule of law is described as a principle that involves treatment of public authorities and individuals within the law. As an addition to this commitment, some authors believe that the rule of law implies the exercise of democracy, justice, equality and other values.

The notion of "rule of law" stems from many traditions and continents and interfere with the development of the history of the law. Code of Hammourabi, promulgated by the king of Babylon around $1760 \mathrm{BC}$, is one of the first codifications of law, presented to the public concerning the acts of the king. In the Arab world, a rich tradition of Islamic law embraced the idea of the rule of law. The main principles of holding government authorities to account and setting the wishes of the people before the rulers can be found in terms of the moral and philosophical traditions across the Asian continent. In continental Europe notions of the rule of law focused on the character of the state, especially regarding the role of constitutionality.

In the Anglo-American context as Claire Breay, Julian Harrison (2015) describe, the Magna Carta of 1215 was crucial document, stressing the importance of the independence of the judiciary and the role of the judicial process as the main characteristics of the rule of law. This iconic document is not intended to be a permanent declaration of legal principle. It was a practical solution to the political crisis of the 
highest ranks of feudal society, but it included the first reference to what has become known as due process, and so was the first significant step in the process of guaranteeing the constitutional freedoms that continues 800 years later. Sir Edward Cook interpreted as a declaration of individual freedom in the conflict between the Commons and King Charles I, and it has a resonant echoes in the US Constitution and Bill of Rights.

Within the United Nations is a pretty broad definition of the rule of law as a principle which provides: accountability and transparency in the work of all legal entities (including public authorities), making the procedure for the adoption and publication of laws and other legal acts, the uniform application of laws and other legal acts, respect for human rights and the norms and standards of international law. Principles of the rule of law, according to the lean-division, aims to provide uniformity and accountability before the law, fairness in the application of law, separation of powers, participation in decision-making, transparency and protection against arbitrary behavior and decision-making.

Rule of law in modern legal systems is accepted as a fundamental principle that is in direct correlation with the legal state, democracy and the realization of human rights and freedoms. More recently the principle of rule of law is linked to economic growth and development of a country.

\subsection{ESSENTIAL ELEMENTS OF THE RULE OF LAW}

According to USAID essential guide (2010) there are five elements comprise the rule of law. Each must be present for rule of law to prevail. The elements are:

* Order and security - Rule of law cannot flourish in crime-ridden environments or where public order breaks down and citizens fear for their safety. The executive branch has immediate responsibility for order and security, but the judiciary has an important role as well in protecting rights and providing for the peaceful resolution of disputes.

* Legitimacy-Laws are legitimate when they represent societal consensus. Legitimacy addresses both the substance of the law and the process by which it is developed. This process must be open and democratic. In some societies, legitimacy can be derived through religion, traditions, customs, or other means. Laws do not need to written in order to be legitimate, since traditional/customary laws are often passed on through oral traditions.

* Checks and balances - The rule of law depends on a separation of governmental powers among both branches and levels of government. An independent judiciary is seen as an important "check." At the same time, checks and balances make the judiciary accountable to other branches of government. Like all branches, the judiciary is also accountable to the public. An independent and strong bar association can also help support the judiciary and serve as a check against judicial power.

* Fairness: Fairness consists of four sub-elements:

$>$ Equal application of the law,

$>$ Procedural fairness,

$>$ Protection of human rights and civil liberties, and

$>$ Access to justice.

These subelements are key to empowering the poor and disadvantaged, including women. The justice sector bears primary responsibility for ensuring that these sub-elements are in place and implemented. 
- Effective application-This element pertains to enforcing and applying laws. Without consistent enforcement and application for all citizens and other inhabitants, there can be no rule of law. The judiciary is an important element of the enforcement process.

The search of universal indicators and comparative rankings on developed and developing countries can make us lose sight of the common wisdom that "one size really does not fit all".

\section{RULE OF LAW AND ECONOMIC DEVELOPMENT}

Contemporary legal theory and economic science explores the link between the principle of the rule of law with the economic growth and development. According to S. Haggard (2011) it is considered that the rule of law determines economic development in a way that ensures: safety of subjects in law, protection of property rights, the realization of obligations, government control and protection of corruption. As safety of subjects in the law, it still implies the creation of a legal system that establishes public order. In this regard it suggests that the exercise of freedom of market and entrepreneurship, and the protection of ownership rights is possible only if the entities acting on the market or the holders of the property feel confident. Armed clashes and growing crime negatively affect economic development because thus decrease the feeling of security among the entities that are part of the market. Legal protection of the right to property and realization of obligations are also considered a key factor in economic development.

Namely, according to the views of legal theory, if the legal system is no guarantee of the right to property, and legal mechanism which provides protection as the right to property and the fulfillment of obligations, then it provides legal certainty for the entities market which actually leads to increased investment in the country.

Long-term control of government by the rule of law, according to legal theory and economic science significantly affect economic development. Control of the government in this regard should primarily include restriction and control of discretionary powers of the executive, then establishing legal system in which the state would be obliged to fulfill its obligations towards the subjects in the law, and establishing an independent judiciary.

Limiting the discretionary powers of public authorities who decide on subjective civil rights is a prerequisite for effective protection of the right of ownership and other real rights. The establishment of a legal system in which the state would be obliged to fulfill their obligations, it is seen as crucial to achieving the obligations in that entity as part and state. The independence of the judiciary, is also treated as one of the basic assumptions as to protect the right of ownership and other similar rights. Moreover, it suggests that the degree of independence of the judiciary primarily assessed through the method of selection of judges and the duration of their mandate and power-accessories control of the judiciary through the budget, control at work and so on.

In their book "Regimes and the Rule of Law: Judicial Independence in Comparative Perspective", G. Helmke, R. Rosenbluth claim that the independence of the judiciary for developing countries is essential in terms of protecting civil rights. In this regard undoubtedly only professional and competent judges can contribute the realization of the rule of law in the protection of civil rights. Implementing the principle of the rule of law implies the protection of corrupt behavior within the state institutions such as receiving bribes, commissions etc. In a broader sense, the protection of corrupt behavior includes provision of equality and fair treatment of the subjects before the law, especially as participants in those legal relations appear natural or legal persons on the one hand, and the state or its organs on the other side.

There is no doubt that corrupt behavior has a negative impact on economic development because it increases the costs for potential investors and creates a situation in which there is protectionism and 
monopolistic behavior in the market. Also, corrupt behavior could compromise the legal protection of rights of ownership if expropriation is used for taking away the right of ownership of a person in favor of another. In a broader sense, as P. Keefer (2004) emphasizes the emergence of corruption reduces the confidence of stakeholders in the judicial system as an institutional framework through which ensures protection of the right of ownership and other real rights as well as the realization of obligations.

The significance of the principle of rule of law in economic development, in addition to theoretical and empirical debates encourages the research "Measuring principle of the rule of law" that should show the degree of realization of this principle in the legal systems of some countries. These surveys are conducted within institutions such as the World Bank. In view of these research sciences M. Kurtz, A. Schrank (2007) believe that is still debatable which indicators should be considered to be a true picture of the extent of the rule of law in the possession of a particular country. In this direction, some theorists like E. Glaeser et. al., (2004) give priority to subjective indicators (experience of the experts, investors and citizens), and others on objective indicators (legal system and institutions).

\section{RULE OF LAW ACCORDING TO THE CONSTITUTION OF REPUBLIC OF MACEDONIA}

The implementation of the rule of law in all its dimensions (legal, political, economic) is still a challenge for every country in the world, especially to developing countries and transition economies such as the Republic of Macedonia.

Macedonia's commitment to implementing the principle of the rule of law is reflected primarily by the Constitution Macedonia (Official gazette of RM 52/92). Article 8 of the Constitution stipulates that one of the fundamental values of the constitutional order of the Republic of Macedonia is the rule of law. The fundamental values of the constitutional order of the Republic of Macedonia are: the basic rights and freedoms of man and citizen recognized in international law and set down in the Constitution and the free expression of national identity;

In addition principle the rule of law as fundamental values of the constitutional order of the Republic of Macedonia are listed: free expression of national identity; division of state powers into legislative, executive and judicial; political pluralism and free, direct and democratic elections; legal protection of property; free market and entrepreneurship; humanism, social justice and solidarity; local government; regulation and humanization of space and protection and improvement of the environment and nature and respect for the generally accepted norms of international law. It should be borne in mind that the exercise of the fundamental values set out in Article 8 of the Constitution is closely linked to the exercise of the rule of law. In fact, in legal theory realization of the rule of law in the broadest sense is associated with the development of democracy, protection of civil rights, separation of state powers, protection of tenure and protection free market and entrepreneurship. In this regard the said provision clearly expresses the intention of the constitution the rule of law to be implemented in all areas of legal life in the country. In order to achieve the rule of law in civil relations of particular importance to the constitution is to guarantee right to property, legal protection of property and the guarantee of freedom of the market and entrepreneurship.

It is undisputed that Article 8 of the Constitution contained a constitutional guarantee of legal protection of property right in the country. The constitutional guarantee of the right to property which by its nature is a property, i.e. real subjective right, not only in Macedonia but also in comparative law shows that this protection is achieved at the highest level, i.e. it is guaranteed by the highest legal acts that protect basic human rights and freedoms. The reason for this approach to protecting the right of ownership certainly stems from the importance which it has ownership of entities in law. Despite the proclaimed protection of the right to property under article 8 of the Constitution, it finds it in the provisions of Article 30 of the Constitution: "The right to property and inheritance rights. Ownership creates rights 
and duties and should serve the wellbeing of the individual and the community. No person may be deprived of property or of the rights deriving from it, except in the case of public interest defined by law. In case of expropriation of property or restricted property is guaranteed just compensation not lower than its market value."

It is necessary to indicate that the Macedonian legal theory outlined several observations regarding the proclamation of paragraph 1 of Article 30 of the Constitution. They are due to the same questionability at the same time as the guarantee the right to property and inheritance rights. In fact, the wording of the constitutional provision provides that the constitution has in mind only private property in its individual form because it becomes correlated with the right of inheritance which only individuals can exercise. To avoid disruption to the edge of the Constitutional Court of Macedonia Republican-legal theory holds that this constitutional provision should be interpreted as a guarantee of the right to private property, or as a guarantee of individual private ownership and group of private ownership (ownership of legal entities) as Rodna Zivkovska in her book Stvarno Pravo (2005) explains. As for the guarantee of the right to property of physical and legal entities, prof. Zivkovska emphasizes that it is important to know that it has no absolute character. This conclusion derives from the provisions of paragraph 3 of Article 30 according to which the right of property may be revoked or restricted, but only when there is a need for achieving public interest determined by the law. Then, in case of suspension and limitation of the right to property under the provisions of paragraph 4 of Article 30 of the Constitution guarantees fair compensation cannot be lower than the market value. In the legal system of the Republic of Macedonia expropriation and restriction of the right of ownership because of public interest is regulated by a special law on expropriation. (Official gazette RM 95/12). In order to ensure the smooth realization of legal relations in accordance with the principle the rule of law, end a constitutional guarantee of the right to property and the legal protection of ownership, the Constitution contains provisions to protect the free market and entrepreneurship. Pursuant to the provisions of Article 55 of the Constitution "freedom of market and entrepreneurship the republic ensures an equal legal position to all market participants. R. Macedonia takes measures against monopolistic positions. Free market and entrepreneurship can be restricted by law solely for the defense of the Republic, protection of nature, environment or human health."(Ibid.)

Constitution, despite proclaiming the freedom of the market and entrepreneurship, with the provisions of Article 55 prescribes the responsibilities of the state (Republic of Macedonia) in ensuring equal legal position in the market and the protection of creation of a monopoly position in the market and monopolistic behavior of subjects market. The fulfillment of this obligation for the Republic of Macedonia in the spirit of the rule of law certainly implies the adoption of legislation by providing for equality of subjects in legal relations at the same time prescribes measures and instruments for the creation of a monopoly position on the market and protection from monopolistic behavior appeared not in accordance with the proclaimed equality of the subjects in legal relations (Law of obligations 18/01) should not overlook the position of the legal theory under which the equality of the subject's relations in legal relations includes state authorities as well which on behalf Macedonia enter into legal relations. This means that the field of law all subjects of law, including state bodies, should be located in an equal legal position with regard to obtaining civil subjective rights (none of the subjects has privileged position or will that can subject to the other entity in that relationship). The same is true with regard to the fulfillment of civil subjective obligations which apply to state authorities also are obliged and responsible to fulfill the commitments entered into legal relations.

It should be indicated that with the provisions of Article 55 of the Constitution it is possible to limit the freedom of the market and entrepreneurship, but only for achieving certain goals such as the defense of the Republic, preserve the nature, environment and protection of health. (Article 55 Constitution of $\mathrm{RM})$.

When it comes to the rule of law and freedoms of the market and entrepreneurship the literature often mentions the conclusion that in contemporary legal systems come to the realization that the free market 
and entrepreneurship without establishing rule of law. Economic science in this direction asserts that there are empirical studies that show the link between the rule of law and economic development of a country. Thus, based on a survey of the economic development of the more than 100 countries worldwide in the period from 1980 to 2000 found that countries where there is high index ranking of the legal system (The Legal System Area of The Fraser Institute's Economic Freedom of the World index), higher than 7 out of a possible 10, as J. Gwartney and J. Clemens (2004) underline, they were countries with more stable economic development during those two decades. In contrast to this low economic development seen in countries that had established low index ranking of the legal system or index lower than 4:20 as a basis for determining the index ranking of the legal system, among others, were considered: protection the right of ownership, providing impartial fulfillment of contractual obligations, an independent judiciary and the rule of law.

It can be concluded that the establishment of the rule of law in economic relations as a sphere in which to realize the freedom and entrepreneurship implies, first, the existence of a corresponding legislation. However, economic science question the extent to which the state, through law, should participate in the regulation of economic relations is still open to debate. In contemporary economic theory article by B. Z. Tamanaha, "The Dark Side of the Relationship Between the Rule of Law and Liberalism" (2004) theory of classical liberalism is explained that the State should have a very small role in regulating the free market and entrepreneurship which amounts to ensuring protection of property, life, health and freedom and all the other "interventions" the legislation to be considered undesirable. It concluded that contemporary economic theory actually aims to embrace the rule of law as an instrument through which a country will provide free market and entrepreneurship, and will install objective limits where freedom can be achieved, and the order will prevent its abuse.

\section{EU ROLE AT THE RULE OF LAW AND ECONOMIC DEVELOPMENT STAGE}

EU membership for each state means the state's responsibility to implement the right of EU on its territory, because the rule of law is the basic precondition for membership. Means, every entity is to be placed in an equal position before the law, no matter his/her party, ethnic or any other affiliation. Also means that the constitutional institutions should function on the basis of the Constitution and the law, without the dominance of any of the institutions, but with mutual collaboration and compliance. According to EU Law only depoliticized public administration and judiciary with professional capacity and integrity can guarantee rule of law in Republic of Macedonia.

Charter of Fundamental Rights and the European Convention on Human Rights jurisprudence of the European Court of Human Rights and the Court of Justice should be benchmarks for human rights in the country. Urgent is the application of European standards for freedom of expression and freedom media.

Ensuring the rule of law implies the implementation of any law enacted and another rule equally to all, predictability for each subject for the consequences of decisions laws and legal certainty. The fight against corruption should be non-selective and effective. Cooperation in justice and home affairs European institutions, Member States and regional frameworks, based on the agreed and loyal synergies, it will provide the Republic of Macedonia into the European space freedom, justice and security.

\section{ABOUT THE MACEDONIAN COURT SYSTEM}

According to EU commission (the commission) report (2014) the legislative charter which regulates the state's judiciary, as well as his physical and technical organization has been developed considerably as a result of thorough reforms implemented over the past decade. Numerous important issues faced by 
all aspirant countries have been solved, including the removal of accumulation of cases in courts, the establishment of the Academy of Judges and Prosecutors, formal the Judicial Council, the introduction of a system of administrative justice and advancement of legislation on civil and criminal procedure. As an outcome, the country has advanced phase requiring more complex improvements and advances. This refers to the necessity to ensure not only structural but functional autonomy of judges, improving the quality of justice and criterions of service to people, increasing the rate and the value of the judicial system, improved strategic planning, enlarged use of non-judicial remedies and alternative dispute resolution and advanced access to justice for the more vulnerable members of society.

Part of the main tasks is the growing concern expressed in terms of selectivity and impact law enforcement and the judiciary. The basic principle of the rule of law, justice not only must be achieved, but must also see that is fully comprehended and respected by the authorities in relation to the actions of law implementation aimed at specific individuals or sectors. While judicial structure is legally independent of outside influences parliament and executive, individual judges also must act independently of any form of pressure, otherwise public trust will be lost and the rule of law brought in question. Also systemic improvements are to the quality of justice, particularly clearer argumentation and transparency of court decisions; greater and more consistent use of the practice of higher judicial instances and case law of the ECHR (to improve the predictability and legal certainty for individuals and businesses that use courts) and widespread implementation of existing codes of ethics. It requires enhanced protection to ensure that judicial appointments and promotions are based on merit.

\section{ABOUT DEALING WITH CORRUPTION}

The legal and institutional framework and the ground constantly build record of investigations, trials and judgments. Assembling data of hundreds of corruption cases started in 2009 and over 30 cases of high-level corruption started in 2004, all of which are now subject to continuous monitoring the investigation to the final verdict. Yet, in practice are to be seen more actual results, both in view of the decrease and the distraction of corruption. The human and financial resources of the various bodies' enforcement and supervisory agencies remain frail and their powers, status, impartiality and acknowledgment should be reinforced to engage in effective operations. Inter-agency collaboration communication still needs to progress, and the exchange of information and sharing is partial. As the report follows the difficulties include the lack of IT (information technology) connectivity between the courts and the Office of the Public Prosecutor and the lack of a central registry for public officials, and that impedes the surveillance work of the state commission against corruption. Lessons learned from past anti-corruption policies and measures should be practiced more efficiently. Currently negligible strategic planning in this area and future policies needs to improve focus on the real problem areas, including public procurement corruption in politics and high-level corruption. Urgent measures are needed to raise awareness and greater political commitment. There are still allegations of selective enforcement and political influence in this area and requires a more proactive stance to eliminate these serious issues. Public confidence in anti-corruption bodies remains weak. As is the case elsewhere in the region, corruption remains prevalent in many areas and continues to be a serious problem.

Many authors have researched and written great deal about corruption. One of my favorite findings so far is that corruption is directly linked with low level of FDI (foreign direct investment).

The report states that investment activity slowed significantly in 2013 year, temporarily improving in the first quarter of in 2014, before being delayed. Private consumption contributed positively to GDP growth in 2013 and remained resilient in 2014. Industrial production grew significantly from fourth quarter of 2013 onwards, mainly due to strong recovery of production. GDP per capita remains about $35 \%$ the EU average. The current account deficit declined in $20131.8 \%$ of GDP as a result of improving the balance of trade in goods despite a decline in the current transfers. In the same period, boosted inflows of foreign direct investment (FDI), in 2013 they amounted to $3.5 \%$ of GDP, the same level in 
the first half of 2014. In the same period dropped the current account deficit to $1.7 \%$ annually as a result of renewed growth in transfers despite the increase in foreign trade deficit. Rising government borrowing abroad and the rise of foreign loans to public enterprises were the main drivers behind the gradual increase in gross external debt. At the end of the first quarter of 2014, it stood at $66 \%$ projected GDP increased further since then as a result of the issuance of government Eurobond of EUR 500 million in July. Looking ahead, as expected inflow of transfers to remain volatile, foreign investment and government borrowing abroad will have to bear the impact of financing of the current account deficit, which is likely to increase slightly in the short term, given the significant needs for imports arising from public infrastructure projects and establishment of new foreign entities.

\section{ABOUT DEALING WITH ORGANIZED CRIME}

As the report says in 2013 Macedonia gained access to the platform Siena Europol, which significantly reinforced the exchange of data with bodies Law Enforcement European Union. Like in previous years, there were many successful police operations against organized groups, particularly the termination of international routes for drug trafficking and smuggling of migrants. Ministry of interior prepared a record of all cases of organized crime and corruption in 2008, but further efforts are required to monitor all cases of the investigation to final punishment, including through improved feedback and exchange of information between authorities law enforcement, prosecution and the courts. The capacity to fight organized crime remains complicated by the fact that neither the national coordination centre for combating organized crime or national intelligence database still does not function, and there are delays in the establishment of investigative centers envisaged in the new Law on Criminal Procedure.

\section{ECONOMY BENCHMARKS}

When reviewing the developments in the economy of Macedonia, the Commission guided by the conclusions of the European Council in Copenhagen in June 1993, stating that EU membership requires the existence of a functioning market economy and capacity to cope with competitive pressure and market forces within the Union. Following the economic criteria should be seen in the context of the growing role of economic Governance in the enlargement process, as it was welcomed by the General Affairs Council of 17.12.2013. To this end, the ECOFIN Council in May adopted targeted policies to guide country, based on its Pre-accession Economic Program.

\subsection{THE EXISTENCE OF EFFECTIVE MARKET ECONOMY (EU COMMISSION REPORT)}

Motivated by strong external sector and foreign direct investment, economic recovery advanced and to some extent reduced the external imbalances. However, structural strictness and further hinders the proper functioning of the labor market and fiscal discipline and transparency suffer from being managed by instant, ad hoc problems. Though as the report says, the country remains far from the economy in terms of its share in production capital and its intervention in determining prices, the development of a competitive private sector is troubled by difficulties in implementing the agreements, frequent legislative changes without adequate consultation of stakeholders and uneven enforcement regulatory requirements. Implementing reforms to improve the business environment remains proceeding slowly. The development of the national economy depends on building better relationships between companies' foreign investment and local companies which in turn requires the Government and local companies to work to improve the connection of the skills of workers with the needs of jobs and investment activities to greater productivity. Also helpful would be improvements in the areas of entry and exit market. 


\subsection{ECONOMIC POLICY}

The commitment by the government to policies for growth and improving employment, focusing foreign investment and the development of the domestic private sector improved the state of labor market, but as written in the report the unemployment remains stubbornly high, especially among young people. Fiscal discipline and transparency deteriorated further that affected capital spending. As the report states in January 2014, authorities filed the eight Pre-Accession Economic Program (PEP), highlighting key economy, fiscal and structural reforms for the period 2014-2016. Macedonia's macroeconomic and fiscal framework is some extent optimistic gradually increasing growth averaging close to $4 \%$, driven by domestic demand and the gradual reduction in the proportion of the general government deficit to $2.6 \%$ in 2016 . The opinion of the EU commission is that the country should redouble its efforts in line with the conclusions of the Ministerial dialogue between ministers Economy and Finance of the EU and candidate countries from May 2014, in order to strengthen the medium-term budget planning and its implementation and to improve the employability of workers. In accordance with the same conclusions, further struggles are needed to improve the business climate, especially for procedure regarding market exit and access to finance.

In general, there was a political consensus on the fundamentals of a market economy, but economic policy and public expenditure management mainly are focused on momentary problems, not on longterm needs of the economy.

\subsection{UNEMPLOYMENT}

According to the commission report the youth unemployment remains over $50 \%$ and four out of five registered unemployed are unemployed for a year or more. In 2013 the employment rate remained relatively low at $50.3 \%$ and the participation rate of the labor force amounted to $70.4 \%$. While employment in the second quarter of 2014 was $1.3 \%$ higher than a year earlier, much of the new jobs as the previous year, were rough sectors in the underground economy - fueled by public subsidies - in agriculture as well as in the public sector underpinned by a significant increase in active measures for the labor market. More recently, the impact of employment by new foreign entities became evident in the increase in jobs production. Although not provided any published complete information about public employment, it is considered that its share of total employment has remained around $20 \%$. The commission says that the labor market remains marked structural rigidity, such as low labor force participation, lack of mobility workers between sectors inadequate linking workers' skills with the needs of working places and slow reform of the system of training and education, innovation activity weakened by businesses and low labor productivity. Overall, reforms to tackle structural rigidity of the labor market achieved only limited progress. Employability of workers should be improved by structural measures, as well as better targeting of the active measures labor market. Monetary policy continues to successfully defend the currency peg. Inflationary environment remained benign, creating room for monetary policy to stimulate the sluggish credit growth. The commission thinks that increasing the consumer price index (CPI) averaged $2.8 \%$ in 2013, down about 0.5 percentage points in 2012 and dropped further in the spring of 2014, mainly due to falling prices food and housing and services. After a three-month long inflation, consumer prices rose again in July, regulated electricity prices for households rose, and prices of food they stopped decreasing. After several cuts in key rates in monetary policy in January and July 2013 and the adjustment of the reserve requirement to encourage bank lending local currency, the Central Bank has reduced to zero fee for mandatory reserve deposits in November 2013, but the lending and deposit rates slowly decline. 


\subsection{THE EU COMMISSION ON RM MARKET ENTRY AND EXIT FROM IT}

As commission emphasizes, the government project "regulatory guillotine" has made some progress in facilitating market entry, focusing on reducing the administrative burden and measures for SMEs (small and medium sized enterprises). Though, businesses continues to face difficulties in obtaining licenses and permits - procedure "one stop shop" is progressing slowly and needs to expand the business beyond building permits. Particular problem is the barriers to starting a private business, as they tend to hinder the establishment (import substitution) of supply chains between technological advanced foreign entities and domestic private economy. Improvements exit procedures market remains more limited. The commission underlines that the number of bankruptcies and erasures from the trade registry cut in 2013 between September 2013 and May 2014 it was lower by over 40\% compared to previous year. Regardless of previous reforms to speed up the proceedings, only $20 \%$ of bankruptcy proceedings were concluded in 2013, considerably less than in 2012 (35\%). In order to further strengthening procedures for exiting the market, legislation was amended to impose shorter deadlines the bankruptcy proceedings and allow extra-judicial dispute resolution in cases of insolvency.

About the free economic zones, the EU commission feels that local companies do not enjoy the same benefits as foreign companies in terms of encouragements. The conditions for obtaining public assistance are fully in favor of foreign companies because local companies can rarely achieve the required amount of the investment. Government debt is still the problem of liquidity of businesses despite recent tightened legal requirements. Overall, though starting a business became slightly easier, difficulties regarding obtaining permits remained. The procedure for exiting the market continues long, although the government has taken some reform steps in the right direction.

\section{EU COMMISSION ON THE LEGAL SYSTEM}

The commission report states that the government continued to implement the judicial reforms aimed at speeding up procedures and improve capacity, particularly by upgrading information systems and electronic delivery. At the end of 2013, the number of cases waiting to be resolved decreased by $9 \%$. The implementation of the agreements continued, it remained problematic for private companies with long and costly legal procedures, ineffective procedures permitting and often unequal application of laws. The size of the informal economy continued to hinders competitiveness and development of the formal private sector. There is little information available about Action Plan 2013 of the Ministry of Labor to reduce the informal economy and Minister unveiled a similar plan in 2014 without clear evidence of assessment based on results previous measures. As written in the report, the business is still overloaded by new legislation without sufficient public consultation. In total, the legal system for a functioning market economy is primarily functional, but in practice there are inefficiencies because of the lengthy procedures that delay enforcement. Frequent changes of laws create legal uncertainty.

\section{THE COMMISSION'S REPORT ON SECTOR STRUCTURE AND ENTERPRISES}

No noticeable change in the sectorial structure of the economy. $36 \%$ trade with automotive services prevailed in the enterprise sector. The commission report says that the share of agricultural production in the economy remains unchanged at about $10 \%$. Mainly because of faltering recovery in manufacturing sector in 2013, manufacturing and services fell by about $21 \%$ in 2011 to $16 \%$ in 2013 . The construction industry has gained in importance, accounting for about $10 \%$ of gross value added in 2013, rising from 7\% in 2011, driven to some extent by public infrastructure investments and foreign investment. 
In terms of size, the report says that economy remains dominated by micro and small enterprises, which accounted for more than $98 \%$ of all companies in 2013 . The number of large companies has more than doubled, driven the establishment of companies with foreign investments, although their share remains below $1 \%$. The small and medium enterprises account for over $80 \%$ of total employment, with a slight decrease in the share of large companies to below $20 \%$. Overall, the sectorial structure and corporate structure of the economy remains unchanged and is focused on low-productivity activities. The increasing number of large companies indicates to the commission that the share of advanced manufacturing activities in the economy could strengthen somewhat in the coming years, but real sectorial transformation remains unreachable.

\section{EU COMMISSION ON COMPETITIVE MARKET- THE ROLE OF THE STATE}

Possession of the economic capital of the state has remained relatively modest at about $15 \%$ of GDP. As written in the commission report, the legal framework for state aid is strengthened by the adoption of regulations for regional support, horizontal aid and amenities of general economic interest, transposing the relevant EU legislation in national legislation. There is limited reporting on state aid. During the second phase of the deregulation of the electricity market, which began in April 2014, 222 medium and large companies began to buy electricity on the open market. Yet, without prejudice to these developments, a wide range of instruments through which government policies increasingly influence competitiveness of the economy and the competitiveness of various sectors and companies, such as direct subsidies and tax exemptions, especially for foreign investors; inspections and penalties for firms face place; forced postponement of payment contracts; public guarantees for loans to state enterprises; Public infrastructure projects; and active programs for the labor market. Overall, against the backdrop of small share of the country's economic capital, improved legislation on state aid and additional deregulation of the electricity market, the state's influence competitiveness through the implementation of other policy instruments seems to grow.

\section{ABOUT THE ECONOMIC INTEGRATION AND CONVERGENCE WITH EU}

According to the commission report total trade in goods and services has remained high at around $126 \%$ of GDP with a total export of 54\% of GDP. In 2013, about 70\% of total exports went to the EU, 7\% more than in 2012 and about $60 \%$ imports come from there. CEFTA was the second most important partner, with about $20 \%$ of exports - less than 2012 - around 12\% of imports. Exports remained highly concentrated $48 \%$ of exports consisted of iron and steel, chemicals and clothing. However, diversification continued, mainly on account of foreign investors, helping gradual transition to products with higher added value, such as machinery and transport equipment their share in total trade increased to over $13 \%$ in 2013 , from less than $5 \%$ in 2008. Companies from the EU fell to around $80 \%$ of total foreign direct investment stock at the end 2013. GDP per capita has remained around $35 \%$ of the EU average in 2013. Overall, trade relations with the EU have increased further in 2013, in the areas of export and imports and the EU remains credited for the bulk of FDI (foreign direct investment).

\section{CONCLUSION}

We need strong institutions and strong legal framework to have economic development.

This notion abandons laissez faire way of reasoning and in my opinion is right for law creates all economic ingredients. 
Law provides the bases for economic motion: money, property, capital, and labor, contracts: law doesn't just legalize these things it creates them. At the same time, whatever our legal framework, we need an effective public institutions to carry it out. Effective public institutions are rare, expensive, difficult to develop and easy to untangle. They have many parts, each of which may be more or less effective. The powerful consensus that the ROL is essential makes it hard to remember that this doesn't tell us a great deal.

The search of universal indicators and comparative rankings with USA, EU etc. can make us lose sight of the common wisdom that "one size really does not fit all".

However there are several ideas that are shared among developed countries, as David Kennedy, would underline in his research "Investing in the Rule of Law, Justice and Security for the Post 2015 Development Agenda".

First: the idea that the legal foundations for market activity must be transparent and effective. To generate development, a market economy requires:

1. Strong property rights and

2. A reliable judiciary to enforce them.

As mentioned before the Constitution of the Republic of Macedonia guarantees an investor's right to property. No person may be deprived of his/her property or the rights deriving from it, unless the use of that property affects the general welfare of the public.

If the property is expropriated or restricted, rightful compensation of its market value is guaranteed. If the foreign company registers a local company according to Macedonian law, it can acquire land with full ownership rights similar to a domestic company

Second: the idea that development requires "good governance"- an effective public administration, a reliable police and security establishment, and the elimination of corruption.

In some sense: where law is the instrument of one or another development policy, the policy can only be as effective as the public hand that wields it.

But an effective public hand is itself an enormously expensive resource to build, maintain and deploy. A small number of countries do it well.

Third: Development is simply impossible without Human rights. Human rights give security and stability to people - liberating a country's economic potential. Or, put differently, human rights are the crucial part of development. A country that respects human rights has better development results than one that doesn't.

Finally I have several points that I would like to underline as something to think about.

-Corruption is statistically associated with low level of FDI.

-Countries of the region should turn to each other to improve the economic situation. Around $15 \%$ of total trade is intra trade.

- $80 \%$ of the investors do not bring new technologies to the region because of deficiencies in human capital.

- Infrastructure development is still critical- highways that connect ports are urgently required. 
- Small and medium businesses of Europe may feel more comfortable in the smaller markets of SEE countries.

- Indicators of World Bank doing business report matter- companies take into account these scores before investing.

I will end this essay with a quote from Ban Ki Moon- United's Nation General Secretary "Businesses succeed when societies themselves succeed. When countries are affected by violence and the absence of the rule of law, business can and must be a messenger of peace."

\section{REFERENCES}

B. Tamanaha, A Concise Guide To The Rule Of Law, Legal Studies Research Paper Series, September 2007, The Social Science Research Network Electronic Paper Collection, http://ssrn.com/abstract=1012051; G. O'Donnell, "Why the Rule of Law Matters", Journal of Democracy 15, 2004, 33

B. Z. Tamanaha, "The Dark Side of the Relationship Between the Rule of Law and Liberalism", NYU Journal of Law \& Liberty 2004, 516-519; R. M. Ebeling, Free Markets, the Rule of Law, and Classical Liberalism, The Freeman: Ideas on Liberty - May 2004

Claire Breay is Head of Ancient, Medieval and Early Modern Manuscripts at the British Library. She is co-curator of the Library's major exhibition Magna Carta: Law Liberty, Legacy (13 March-1 September 2015) and editor of the exhibition catalogue - See more atError! Hyperlink reference not valid.

Charter of fundamental rights, Official journal of the European communities, 2000

David Kennedy, "Investing in the Rule of Law, Justice and Security for the Post 2015 Development Agenda", Bangkok Dialogue on the Rule of Law, November 15, 2013

E. Glaeser et. al., "Do Institutions Cause Growth?”, Journal of Economic Growth 9/2004

Report of the Secretary-General: The Rule of Law and Transitional Justice in Conflict and Postconflict Societies, http://www.unrol.org/doc.aspx?n=2004\%20report.pdf, 2004

G. Helmke, R. Rosenbluth, "Regimes and the Rule of Law: Judicial Independence in Comparative Perspective", Annual Review of Political Science 12/2009, 345-366.

Izvestaj za napredokot na rabotata na Republika Makedonija 2014, Evropska komisija, Brisel, 8.10.2014

J. Gwartney, J. Clemens, Can a Country Prosper without a Sound Legal Structure?, Fraser Forum, July 2004, 3-4.

M. Kurtz, A. Schrank, “Growth and Governance: A Defense”, Journal of Politics 69/2007, 563-569. 12

Paul Craig Roberts, The Failure of Laissez Faire Capitalism and Economic Dissolution of the West, 2013Development Agenda", Bangkok Dialogue on the Rule of Law, November 15, 2013

P. Collier, The Bottom Billion, Oxford University Press, Oxford 2007, 27; D. North, J. Wallis, B. Weingast, Violence and Social Orders: A Conceptual Framework for Interpre-ting Recorded Human History, Cambridge University Press, Cambridge 2009. 
P. Keefer, A Review of the Political Economy of Governance: From Property Rights to Voice, World Bank Policy Reseach Work, 2004

Р. Живковска, Стварно право, Скопје 2005

S. Djankov et. al., "The Regulation of Entry”, Quarterly Journal of Economics 117(1), 2002, 1-37.

S. Haggard, "The Rule of Law and Economic Growth: Where are We?", World Deve-lopment Vol. 39, No. 5, 2011, 673

Светомир Шкарич, Уставно право, втора книга, Скопје 1995

Закон за експропријација, Службен весник на Р. Македонија, бр. 95/12, 131/12

Worldwideweb. ec.europa.eu/enlargement documents

Worldwideweb.epi.org.mk/Записник од завршна конференција Мрежа 23, 2015

World wide web.mcgill.ca, The rule of Law and economic development, 2012

Worldwide web. usaid.gov. Guide to rule of law country analysis, January 2010

Worlwideweb.bl.uk/magna-carta/articles/magna-carta-an-introduction\#sthash.M5esTSBf.dpuf 